Service Industries Journal, Volume 22, no. 3, July 2002,

\title{
Differentiation through Service: A Perspective from the Commodity Chemicals Sector
}

Terry Robinson
Reader in Marketing
School of Business \&
Management
University of Teesside
Middlesborough

TS1 3BA UK
Colin M. Clarke-Hill

Reader in Strategic Management

Centre for Research in Service

Gloucestershire Business School

Pallas House, The Park

Cheltenham

GL50 2QF

\author{
Richard Clarkson \\ Research Executive \\ MORI \\ 95 Southwark Street \\ London \\ SE1 0HX
}

\section{Address for correspondence: T.M. Robinson \\ Email: T.M.Robinson@tees.ac.uk}

\begin{abstract}
This paper examines the role of service as a differentiating factor in the marketing of commodity chemicals. The commodity chemicals sector is characterised by high volume products that are fundamentally undifferentiatable by product characteristics, made to an industrial standard often produced with a technology that is common amongst competing producers, with high exit cost due as a result of extensive capital investment. In addition many segments of the market exhibit excess supply over demand.

The research, based on an empirical study of companies in the sector and their supply chain relationships, suggests that service and relationship management are key strategies used by companies to escape the commodity trap and gain competitive advantage. The results of the study are discussed in the context of the services marketing continuum and using the servitisation model.
\end{abstract}

The implications of the findings are that, if firms in this sector wish to break out of the commodity trap of blind allegiance to cost leadership as a generic strategy, then they must seek methods of differentiation.

The paper concludes that a servitisation strategy placed in the context of relationship management can be a means of creating differentiation advantage in a traditionally cost orientated sector. 


\title{
Differentiation though Service: A Perspective from the Commodity Chemicals Sector
}

\author{
Terry Robinson Colin M. Clarke-Hill Richard Clarkson
}

\section{INTRODUCTION}

The paper is reporting empirical work on marketing in the commodity chemicals sector and sets out to challenge the perception that commodities are the epitome of tangible-dominant products/services as defined by Shostack (1977). This paper does not seek to refute some of the laws of physics by suggesting that chemicals are not tangible products. Berry's (1980) characteristics of services as: more intangible than tangible, simultaneously produced and consumed, and less standardised and uniform; would clearly not apply to commodity chemicals although the issue of simultaneous production and consumption will be explored later.

Levitt (1972) radically suggested that:

"There are no such things as service industries. There are only industries whose service components are greater or less than those of other industries. Everybody is in service"

In industrial markets, services are often seen as an add-on or as a necessary evil, since in the mind of most customers and sales personnel an intervention after the sale is associated with a defect in the product. The notion of service can be extended from Levitt's (1969) concept of the 'augmented product' into the realms of 'servitisation' which goes beyond the traditional approach of providing additional services but considers the total offer to the customer as an integrated bundle consisting of both the goods and the services (Vandermerwe and Rada 1988). This approach requires a different managerial mind set in that:

"Management must break out of the mind set that considers manufacturing (or goods production) as separate from the service activities that make such products possible and effective" (Quinn et al 1990)

Diagramatically, this can be shown in Figure 1 below, where the left hand drawing represents a "typical" industrial product offering with service as an additional, but essentially separated adjunct to the core tangible product. The right hand drawings suggest a servitised product where the core product and the service elements are inextricably linked. 
Figure 1 Servitised and Non-Servitised Systems

Non-Servitised

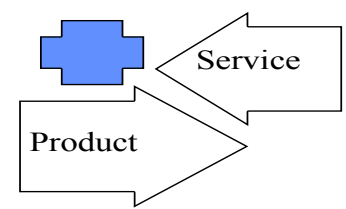

Product with Service as an Add-on Package
Servitised

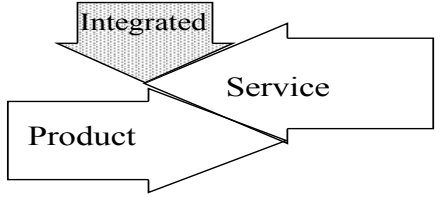

Product and Service

as an Integrated Package

and Inseparable

(Adapted from Van Looy, Van Dierdonck and Gemmel, 1998, p 35)

The term 'commodity' is used widely in the marketing literature and there appears to be some broad consensus as to a definition of commodity products. Generally, it is accepted that commodity products are those products perceived in the market by both buyers and suppliers, as being homogeneous or undifferentiated (Unger 1983, Rangan and Bowman 1992, Sinclair and Seward 1988).

Commodity products can be seen as being a non-differentiated industrial product defined as follows:

"Manufactured to a standard or fixed specification, bought in response to basic and essential needs, and used in markets where purchasing decisions are governed by rational factors".

Typical commodity type products include plywood, salt, plastic tubing, strip steel and six inch nails. The products of one firm are seen by the market as generically and functionally identical to those of the competition.

Most materials and products can be classified into two broad categories: undifferentiated and differentiated. Unger (1983) classifies undifferentiated and differentiated products as follows:

- Undifferentiated materials and products are produced in substantially similar form by a number of suppliers; frequently used in a number of different applications; sold to specifications for what they contain (homogeneous); having, in general, only low or average profitability.

- Differentiated materials and products are produced with real differences among materials and products of different suppliers, or which are, at least, marketed with imputed differences; generally used in only one, or, at most, a few different applications; nearly always sold to specifications of how they perform, or what they do in practical use, having, in general, above-average or high profitability.

In relation to the chemical industry, most kinds of chemical products and therefore chemical businesses can be classified into four different areas. These businesses often blend into each 
other, and the larger chemical companies often are in all four of these businesses at the same time. The following definitions are derived from the works of Unger (1983), Emerson (1983) and Quientella (1993), based on the criteria of undifferentiated/differentiated and high/low volume.

The categories of products are illustrated in Figure 2 below.

Figure 2 Categories of Products

\begin{tabular}{|c|c|c|}
\hline & $\begin{array}{c}\text { Undifferentiated } \\
\text { Products }\end{array}$ & $\begin{array}{l}\text { Differentiated } \\
\text { Products }\end{array}$ \\
\hline $\begin{array}{l}\text { High } \\
\text { Volume }\end{array}$ & $\begin{array}{l}\quad \text { True Commodities } \\
\text { - Sold at relatively low unit values } \\
\text { - Widely used in a variety of applications } \\
\text { by many customers } \\
\text { - Sales concentrated in a few large } \\
\text { customers } \\
\text { - Contract pricing }\end{array}$ & $\begin{array}{l}\text { Pseudo Commodities } \\
\text { - } \quad \text { Produced to accepted performance } \\
\text { specifications but with minor differences } \\
\text { - Sales concentrated in a few large customers } \\
\text { - Some degree of differentiation exists }\end{array}$ \\
\hline $\begin{array}{l}\text { Low } \\
\text { Volume }\end{array}$ & \begin{tabular}{l}
\multicolumn{1}{c}{ Fine Products } \\
- Substantially identical product form \\
and composition \\
- High unit price \\
- Small numbers of customers in low or \\
moderate volumes
\end{tabular} & $\begin{array}{l}\quad \text { Speciality Products } \\
\text { - } \\
\text { - } \text { Pifferentiation by formulation } \\
\text { Produced by various suppliers based on } \\
\text { - } \quad \text { Designed to in use } \\
\text { problems customer's specific } \\
\text { - Relatively high unit price } \\
\text { - Large numbers of customers } \\
\text { - Low volume }\end{array}$ \\
\hline
\end{tabular}

Although these definitions were originally used to describe chemical products and businesses Unger (1983) believes that they can also be used outside the chemical industry. For example he identifies steels as true commodities, papers (tonnage) as pseudo-commodities, precious metals as fine products and speciality papers as speciality products.

Commodity chemicals are typically produced for mature markets and are of a stated industrial standard. The chemistry is widely understood and the plant is run in a low cost manner. The production and engineering strategy is geared around production yields and economies of scale advantages. The technology life cycle concept suggests that as maturity is reached the relative balance between engineering efforts and marketing effort changes. In mature markets, the engineering efforts reduce in favour of that of marketing (Popper and Buskirk, 1992). 


\section{THE COMMODITY CHEMICALS SECTOR AND MARKETING STRATEGY}

Literature referring to marketing of commodity chemicals is relatively limited. Arguably one of the most focused pieces of work is Unger's 1983 article on 'Strategic Planning for Commodities and Specialities' based on research in the chemicals industry. Other work (Wei et al. 1979; Emerson 1983; Stobaugh 1988; Quintella 1993; Black 1994; A.T. Kearney Chemical Industry Practice 1996, 1997; Mitch 1996; Reichheld 1996) have mentioned commodity chemicals, but the sector was not the main focus of the studies.

Unger (1983) suggested that a "commodity chemical company us usually productionorientated with a lower need to have a precise knowledge of customers' requirements". Furthermore, he stated that, although commodity chemical companies require relatively high capital investments for plant; selling, marketing, technical service, general and administrative expenses are relatively low. He concluded by suggesting that commodity chemical companies should follow what he terms a 'size' strategy. This is summarised below:

1. Exercise high selectivity in new investments. Produce only those materials and enter only those markets in which the company can be a dominant supplier.

2. In each material produced, dominate the markets served as one of the top three producers by:

- Entering the market early.

- Developing own processes wherever feasible.

- Constructing large plants for low-cost production, despite their high capital costs.

- Controlling sources of raw materials, and where possible, seeking preferential access to them.

- Getting and keeping a high share of each key market.

- Expanding to anticipate future growth in demand, but making sure competitors are not all expanding to supply the same growth.

- Focusing research and development on process improvement and new applications.

- Keeping marketing, distribution and technical service costs low.

- Seeking captive outlets, where possible.

- Maximising profits by (i) marketing each stage of integrate production sequences product a satisfactory return on the capital investment in it and (ii) concentrating on high-volume markets, applications, customers and grades.

3. Withdraw from marginal businesses where the company does not succeed in becoming one of high-profit leaders.

Arguably this outline strategy makes little mention of service nor, for that matter did Wei et al. (1979) in their work on chemical process industries had argued that a company's share of a commodity market was based mainly on price and partly on reliable delivery and convenience. They suggested that there is relatively little need for technical service and marketing; although they did acknowledge that this was somewhat dependent upon the product and the company's customers. Figure 3 below shows a typical marketing system for a commodity chemicals producer where, service function, although present, is seen as an adjunct to the product from both supplier and customers perspectives. 


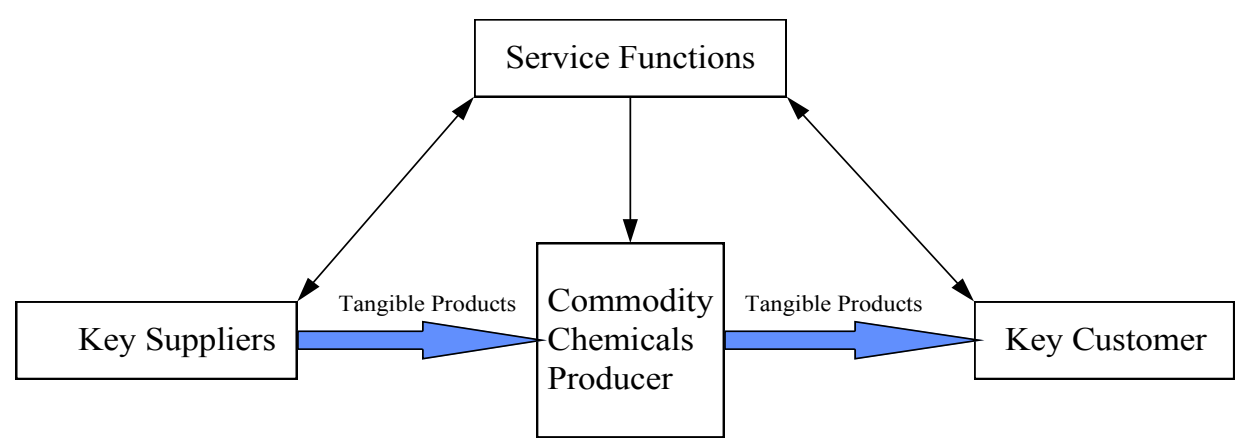

\section{Service as a differentiating factor}

The literature shows (Wei et al. 1979; Emerson 1983; Stobaugh 1988; Quintella 1993; Black 1994) that, in the commodity sector of the chemical industry, a company's marketing is based mainly on price, where relatively little service is required and minimal marketing effort is needed, and the focus of effort is on production efficiency. In contrast, later work by the A.T. Kearney (1996) Chemical Industry Practice, Mitsch (1996) and Reichheld (1996) has suggested the need for building relationships and for a relationship approach in order to build sustainable competitive advantage. However it must be said these authors have not referred specifically to commodity chemical companies.

Mitch (1996) has suggested that a greater interdependency between customers and suppliers leads to a more effective means of doing business. He refers to the emergence of a customersupplier continuum and emphasises the need for customer loyalty and the achievement of supply chain excellence. Reichheld (1996) has argued that "building a business today requires that this old-fashioned virtue (referring to loyalty) be a part of a company's relationships with its employees, investors, and of course its customers"

It can be argued that an important facet of such emerging relationships is the nature and extent of the service provision that effectively augments such fundamentally undifferentiable commodity products. However, in the literature to date, there appears to be no (or very little) previous research referring to the nature of marketing in commodity chemical companies, and hence the need for this particular study. However, Cespedes (1994), has discussed the changing requirements of the marketing function in the marketing of industrial products and the increasing need to focus on multi-functional account teams. Information flow, Cespedes (1994) argues, forms a key part of managing customer relationships.

Porter's generic strategies are still a valuable framework for those seeking a structure for their research (Dess and Miller 1993). His work had been extensively scrutinised both empirically and theoretically and reported in the work of Hambrick (1983); Dess and Davis (1982, 1984); and Dess and Miller (1993). Other empirical work outside of the United States in support Porter's generic strategies is reported by Ahmed (1991) and Morris and Pitt (1993). Although 
Porter's model has seen many criticisms, it still remains a useful analytical tool (Speed 1991; Ghemewhat 1991) if the criticisms and refinements are understood and interpreted correctly. This point is reinforced by Dess and Miller (1993) who state that Porter's work has its limitations, but then no single research effort can fully satisfy all possible criteria. They believe the limitations of Porter's work do not constitute fatal flaws, but merely represent points that need adjustments and refinements.

Dess and Miller (1993) highlight the need for researchers to adapt Porter's work and take into account the criticisms and comments discussed earlier. The main criticisms and refinements that the research needs to be aware of have been discussed earlier. Firstly, the meaning of 'low cost'; secondly the existence of combination strategies; thirdly the effect industry structure and the environment have on strategic choice; and finally the development of differential advantage. These criticisms and refinements need to be considered throughout this research from a methodological perspective and in the research design; right through to interpretation of research findings; and in the drawing of conclusions and recommendations.

According to Porter (1985) a firm following the differentiation strategy provides something unique that is valuable to buyers beyond simply offering a low price. This allows the firm to command a premium price (a price above the average price in the industry); to sell more of its product at a given price; or to gain equivalent benefits such as greater buyer loyalty during cyclical or seasonal downturns.

Unlike the cost leadership strategy, more than one firm can be a differentiator as long as each firm has a unique offering that is positively perceived by customers. For a differentiator to achieve superior performance, it must maintain a price premium that exceeds any added cost of being unique.

Behind Porter's (1985) differentiation strategy is the assumption that buyers will not pay for value that they do not perceive, no matter how real it may be. The belief is that the price premium a firm commands will reflect both the value actually delivered to its buyer and the extent to which the buyer perceives this value. Porter (1985) argued that "a firm that delivers only modest value but signals it more effectively may actually command a higher price than a firm that delivers higher value but signals it poorly". Porter (1985) suggested that a firm's uniqueness in a value activity is determined by a series of basic drivers, analogous to the cost drivers highlighted earlier and identified several specifications that he believed a firm needs to follow when instigating a differentiation strategy.

\section{RESEARCH METHODOLOGY}

This paper is taken from a wider study concerning marketing strategies adopted by companies in the commodity sector of the chemical industry. A convergent methodology, multi-method and multi-trait described by Campbell and Fiske (1959), or what has been called triangulation by Webb et al (1966) formed the basis of the methodology for this research. The choice of this methodology allows the researcher to combine the use of quantitative and qualitative methods within the same study. Webb et al (1966) argue that such an approach leads to greater confidence in the findings than the outcomes from only one method allows. Jick (1979) believes that triangulation has vital strengths and encourages productive research. Yin (1994) 
supports this form of approach as a way of building up case studies that are rich in detail and from which further quantification work can be derived.

This part of the study used extensive in-depth interviews with three commodity chemical producers dealing with chlorine chemicals and their derivatives, acetyls and their derivatives and a producer of surfactants, chemicals widely used as a key ingredient in the manufacture of soaps, detergents and shampoos. The depth interviews were conducted over a period of nearly two years, with a number of key respondents in the three firms and linked the company with a number of its customers and suppliers. The depth studies were designed to map the nature of relationships that the focal company with its customers and suppliers and to show the nature of its evolving marketing strategies in this sector. The three companies that were studied are named Alpha, Beta and Gamma. These names protect the identity of the firms, with whom the researchers have confidentiality agreements. The case studies were conducted with senior members of the firms along with representative customers and a number of suppliers that the firms dealt with. Table 1 lists the personnel involved in the study and their job titles. It is not the aim of this paper to present in detail the findings of the study but rather to present an overview and to examine the paradigm shift that might be occurring in the nature of service relationships. The depth interview phase was based around relationship marketing theory and how commodity chemical companies have adopted such an approach to their business. (Robinson, Clarke-Hill and Clarkson 1999, Clarke-Hill, Robinson and Clarkson 1999) 
Table 1: Individuals Interviwed in the Research

\begin{tabular}{|c|c|c|c|c|}
\hline Company & Customer & Supplier & External & Internal \\
\hline Alpha & $\begin{array}{l}\text {-Sales Manager } \\
\text {-Planning \& Business } \\
\text { Development Manager } \\
\text {-Customer Process } \\
\text { Improvement Manager } \\
\text {-Account Manager } \\
\text {-QA Manager } \\
\text {-Technical Services } \\
\text { Manager }\end{array}$ & $\begin{array}{l}\text {-Buying Manager } \\
\text {-General Manager } \\
\text {-Managing Director }\end{array}$ & $\begin{array}{l}\text {-Group Chief } \\
\text { Executive Officer } \\
\text {-Managing Director } \\
\text {-Regulatory Affairs } \\
\text { Manager } \\
\text {-Planning \& } \\
\text { Business } \\
\text { Development } \\
\text { Manager }\end{array}$ & $\begin{array}{l}\text {-Group Chief } \\
\text { Executive Office } \\
\text {-Personnel Manager } \\
\text {-Functional } \\
\text { Managers }\end{array}$ \\
\hline Beta & $\begin{array}{l}\text {-Account Manager } \\
\text {-Site Manager } \\
\text {-Managing Director } \\
\text {-UK Sales Co-ordinator } \\
\text {-R\&D Manager }\end{array}$ & $\begin{array}{l}\text {-Purchasing Manager } \\
\text {-Commercial Director } \\
\text {-Managing Director }\end{array}$ & $\begin{array}{l}\text {-Commercial } \\
\text { Director } \\
\text {-Managing Director } \\
\text {-Health and Safety } \\
\text { Manager }\end{array}$ & $\begin{array}{l}\text {-Commercial } \\
\text { Director } \\
\text {-Managing Director } \\
\text {-Health and Safety } \\
\text { Manager } \\
\text {-Personal manager }\end{array}$ \\
\hline Gamma & $\begin{array}{l}\text {-Technical Services } \\
\text { Manager } \\
\text {-Manufacturing } \\
\text { Manager } \\
\text {-Business Manager } \\
\text {-QA Manager } \\
\text {-Regional Sales } \\
\text { Manager } \\
\text {-Product Manager }\end{array}$ & $\begin{array}{l}\text {-Technical Services } \\
\text { Manager } \\
\text {-Purchasing Manager } \\
\text {-Plant Engineering } \\
\text { Manager } \\
\text {-Plant Operations } \\
\text { Manager }\end{array}$ & $\begin{array}{l}\text {-Managing Director } \\
\text {-Visitors Centre } \\
\text { Manager }\end{array}$ & $\begin{array}{l}\text {-Technical Services } \\
\text { Manager } \\
\text {-Production } \\
\text { Manager } \\
\text {-Managing Director } \\
\text {-Business Manager } \\
\text {-Personnel Manager }\end{array}$ \\
\hline
\end{tabular}

A later stage of the research collected data through a postal survey to test the hypotheses developed from the case studies. The research question that this paper addresses is the extent to which there are 'key' marketing industry attributes within the commodity sector of the chemical industry and the extent to which service is present as both a key factor and a means of differentiation.

Sixty-two commodity chemical companies returned useable responses, from a sample of one hundred and sixteen. Before the analysis was undertaken, exploratory data analysis was used to gain an initial 'feel' of the data, while identifying possible input errors, missing values, rogue values, outliners and inappropriate responses. Secondly, confirmatory data analysis was undertaken to test the hypotheses, including the reliability and validity of the research data and instrument development. The possibility of non-response bias was explored by the comparison of the survey responses with those of the earlier stage of in-depth case analysis.

This survey analysis was conducted under certain assumptions regarding the interpretation of the research data. The analysis assumed that data collected from a 5-point Likert type scale, technically ordinal in nature, could be used in parametric tests. Lord (1953) suggested that parametric tests can also be applied to ordinal data, since tests apply to numbers and not to what those numbers signify. Easterby-Smith et al. (1991) argued that the results from ordinal 
data in parametric tests are often both accurate and useful. While Bryman and Cramer (1994) and Taylor (1995) have also suggested the use of ordinal data in parametric tests.

It was assumed that the population of the data need not be normally distributed nor of equal variances. Studies as early as the 1960's (Boneau 1960; Games and Lucas 1966) have shown samples that are not normally distributed, nor of equal variances, do not differ greatly from those that are normally distributed and of equal variances.

Bryman and Cramer (1994) argued that parametric tests are robust and able to withstand violations, (i.e. ordinal data, not normally distributed or of equal variance), though they recommend the use of non-parametric tests with small samples (below fifteen). This view point is supported by Taylor (1995) who believes that parametric tests work reasonably well even if the requirements are not quite met, although recommending a higher minimum sample size of thirty. Nevertheless, the research's sixty-two usable responses is in excess of both Bryman and Cramer's (1994) and Talyor's (1995) recommended minimum sample sizes. Furthermore, only part of the data was not normally distributed or not of equal variances

\section{INDICATIVE FINDINGS}

\section{The In-depth Phase - Emerging Service Relationships}

The companies that formed part of the in-depth section of this study were seen to be practising relationship management techniques. The focal firm had extensive relationships with both suppliers and customers. In some cases, multi-functional teams were in place to look after key accounts. Techniques such as Just in Time, Quick Response and Electronic Data Interchange systems were commonplace. It can be seen that attempts were being made by the companies to use relationships as service attributes in their marketing strategy. See Figure 4 below.

Figure 4 A Typical Marketing System showing integrated service functions and relationship management

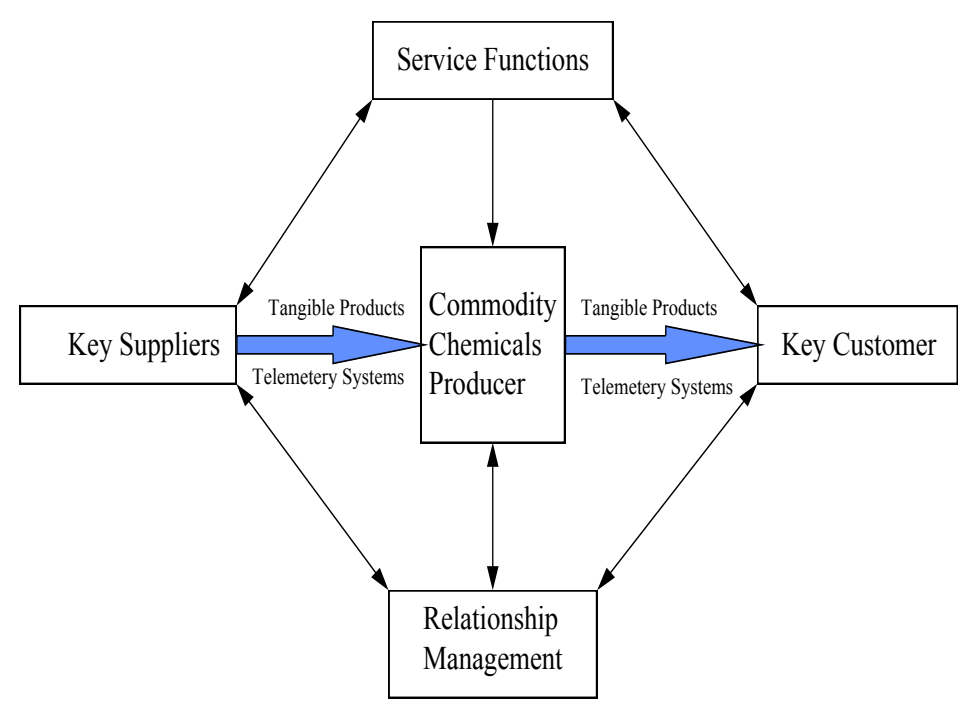




\section{The Survey Results}

One of the aims of the research project was to identify those business attributes that were perceived as important and the relationship of those attributes to perceived business performance. Table 2 below examines the mean rankings of series of attributes and highlights those (presented in upper case) that are of a services nature. Highlighted in bold are those attributes that are significant at the $5 \%$ level whist those suffixed by $*$ are those attributes that are perceived as "key".

The table points out eight service attributes with the attribute "regular contact with customers" as the one that is significant at the 5\% level. Such an attribute is at the very heart of marketing in general and relationship marketing in particular. It can also be argued that service levels can only realistically be developed in the context of frequent customer contact on the grounds that it is somewhat inconceivable that a strong service relationship could be developed without such levels of contact.

To supplement the quantitative data in Table 2, some quotations from respondents in the depth interview stage of the study as well as company documentation are be presented below:

"Alpha seek standards of quality and service which our customers regard as being consistently better than those of competitors" (Alpha 1996).

"Beta's focus is on efficiency and customer service... the key to business success is the way we work with our customers." (Beta 1997).

"All staff will work toward satisfying our customers. We will aim to be our customers' preferred supplier” (Gamma 1996).

Such quotations reinforce the perceived importance of service in the strategy and operational activities of the three case histories examined in the research. 
Table 2 Mean Rankings of Attributes and Correlations with Business Performance

\begin{tabular}{|c|c|c|c|c|c|}
\hline Attribute & Mean & Rank & $\begin{array}{l}\text { Correlation Coefficient } \\
\text { with business } \\
\text { performance mean }\end{array}$ & Significance & Rank \\
\hline Product quality* & 4.82 & 1 & \begin{tabular}{|l|}
.3419 \\
\end{tabular} & $\mathrm{P}=.007$ & 5 \\
\hline DELIVERIES ON TIME & 4.81 & 2 & .2062 & $\mathrm{P}=.111$ & 20 \\
\hline Understanding customer needs* & 4.66 & 3 & .2649 & $\mathrm{P}=.039$ & 16 \\
\hline Continuity of supply & 4.63 & 4 & .0147 & $\mathrm{P}=.911$ & 33 \\
\hline Reputation* & 4.56 & 5 & .3083 & $\mathrm{P}=.016$ & 8 \\
\hline Accuracy of orders* & 4.55 & $=6$ & .2788 & $\mathrm{P}=.030$ & 13 \\
\hline Complaints handling procedures & 4.55 & $=6$ & .0526 & $\mathrm{P}=.687$ & 30 \\
\hline Health, safety and environmental doc. & 4.46 & 8 & .1255 & $\mathrm{P}=.335$ & 29 \\
\hline Track record with customer & 4.45 & 9 & .2016 & $\mathrm{P}=.119$ & 23 \\
\hline Health, safety and environmental record & 4.44 & 10 & .0473 & $\mathrm{P}=.717$ & 32 \\
\hline $\begin{array}{l}\text { REGULAR CONTACT WITH } \\
\text { CUSTOMER }\end{array}$ & 4.42 & $=11$ & .4337 & $\mathrm{P}=.000$ & 1 \\
\hline Cleanliness of tankers & 4.42 & $=11$ & .2747 & $\mathrm{P}=.042$ & 14 \\
\hline EMERGENCY RESPONSE A\&P & 4.40 & 13 & .3162 & $\mathrm{P}=.014$ & 7 \\
\hline Working together & 4.32 & 14 & .2336 & $\mathrm{P}=.070$ & $=17$ \\
\hline Quality control procedures & 4.29 & $=15$ & .3004 & $\mathrm{P}=.019$ & $=9$ \\
\hline $\begin{array}{l}\text { TECHNICAL SERVICE AND } \\
\text { ASSISTANCE }\end{array}$ & 4.29 & $=15$ & .2037 & $\mathrm{P}=.115$ & $=21$ \\
\hline Forewarning of supply problems & 4.21 & 17 & .2813 & $\mathrm{P}=.028$ & 12 \\
\hline Flexibility of lead times \& dev. dates & 4.18 & 18 & .1883 & $\mathrm{P}=.146$ & 25 \\
\hline Price competitiveness & 4.15 & 19 & .1607 & $\mathrm{P}=.216$ & 26 \\
\hline TECHNICAL INFORMATION & 4.13 & 20 & .2682 & $\mathrm{P}=.037$ & 15 \\
\hline Invoicing system & 4.11 & 21 & .3536 & $\mathrm{P}=.006$ & 4 \\
\hline Authority of sales contact & 4.05 & $=22$ & .3028 & $\mathrm{P}=.019$ & $=9$ \\
\hline Product range & 4.05 & $=22$ & .2110 & $\mathrm{P}=.103$ & 19 \\
\hline ORDER HANDLING PROCEDURES & 4.00 & 24 & .3847 & $\mathrm{P}=.002$ & 2 \\
\hline Speed of response to a change in market & 3.98 & 25 & .3711 & $\mathrm{P}=.003$ & 3 \\
\hline CREDIT TERMS & 3.95 & 26 & .2336 & $\mathrm{P}=.070$ & $=17$ \\
\hline Communication of market trends & 3.77 & $=27$ & .1296 & $\mathrm{P}=.320$ & 28 \\
\hline Flexibility of price negotiations & 3.77 & $=27$ & .0496 & $\mathrm{P}=.704$ & 31 \\
\hline JIT DELIVERY PROCEDURES & 3.68 & 29 & .1449 & $\mathrm{P}=.265$ & 27 \\
\hline Frequency of sales representatives visit & 3.67 & $=30$ & .2059 & $\mathrm{P}=.115$ & $=21$ \\
\hline Partnerships & 3.67 & $=30$ & .2007 & $\mathrm{P}=.124$ & 24 \\
\hline Joint investments & 3.47 & 32 & .3013 & $\mathrm{P}=.019$ & $=9$ \\
\hline Proximity of production & 3.10 & 33 & .3286 & $\mathrm{P}=.010$ & 6 \\
\hline Size of supplier & 3.00 & 34 & -.0184 & $\mathrm{P}=.890$ & 34 \\
\hline
\end{tabular}

Note: Bold indicates significant at the $5 \%$ level. * indicates 'key' attribute. UPPER CASE = service attributes

\section{CONCLUSIONS}

A number of conclusions can be drawn from the study that relate to the marketing of commodity products. The relevant conclusions are listed below:

- Historical cost leadership strategies put little emphasis on service 
- The key service attributes were found to be (in rank order of importance):

1. Regular contact with customers

2. Order handling procedures

3. Emergency response to accident and prevention

4. Technical information

5. Delivery on time

6. Credit terms

7. Technical service and assistance

8. JIT delivery procedures

- Although the above points suggest a series of discrete factors, within a relationship marketing approach, these factors are inextricably linked. The eight key factors can, however, be grouped into three sub categories, namely:

Category A - relationship communication and management focused, consisting of; regular contact with customers, technical information, technical service and assistance, emergency response to accident and prevention.

Category B - relationship logistics focused, consisting of; order handling procedures delivery on time, JIT delivery procedures.

Category C - cost focused, consisting of; credit terms.

This suggests that the key service attributes are intrinsically relationship orientated. The exception being the Category $\mathrm{C}$ variable that is clearly a simple facet of a cost-based strategy. his was clearly corroborated by respondents in depth interviews who identified relationships and service attributes as being important to the marketing strategy of commodity chemical companies.

- Service is arguably the one and only differentiator in the commodity chemical sector and evidence from the depth interviews and survey suggests that firms have recognised the value of service in their augmented product offering.

- Thus it could be argued that the firms that have been studied in this sector have used service and relationship building as a means of reducing transaction costs, and to improve transaction values to both themselves and their customers using Category B variables and in some cases by incorporating supplier production systems seamlessly with that of the customer. This strategic behaviour reinforces the view that firms in commodity chemicals are using a service differentiation route to pursue what is ultimately a cost leadership strategy. This is more like what Dess and Miller (1993) describe as a hybrid strategy.

- An alternative explanation of the firms' strategy could be that they are attempting to use service as a differentiator to overcome a price dominated "commodity trap". This they achieve by adding value to the core product attributes (over which they have little or no control) through augmentation by relationship led service elements. This may provide those firms with the possibility of a firm determined competitive advantage.

- The findings from both depth interview and the quantitative survey suggest that firms in the sector are beginning to perceive that their marketing involves increasing elements of 
service. It could therefore be suggested that commodities are no longer anchored at the tangible dominant end of the services continuum but are more appropriately positioned either in the middle ground or even towards the service-dominant end of the continuum. This reinforces Levitt's (1972) proposition that "we are all in the service business".

\section{IMPLICATIONS FOR MARKETING STRATEGY}

The implications of the above for the firms in the sector are that, if they wish to break out of the "commodity trap" of blind allegiance to cost leadership as the generic strategy, then firms must seek methods of differentiation. The nature of the products and their very definition as "commodities" suggest that this is not possible by manipulating the core product attributes. One cannot differentiate oxygen by giving it a smell or differentiate sulphuric acid by giving it a taste!!!. Such manipulation must be conducted in the augmented product attributes with service in the forefront. The service attributes examined in this paper are by no means the definitive list but at least might provide a starting point for further service strategy development in commodity markets.

Where relationship management at both the supplier and customer end of the value chain occur and there is a blurring of boundaries between tangible products and services, this suggests a servitised system is in place. This is illustrated in Figure 5 below.

Figure 5 An Integrated or Servitised System of Value and Relationships

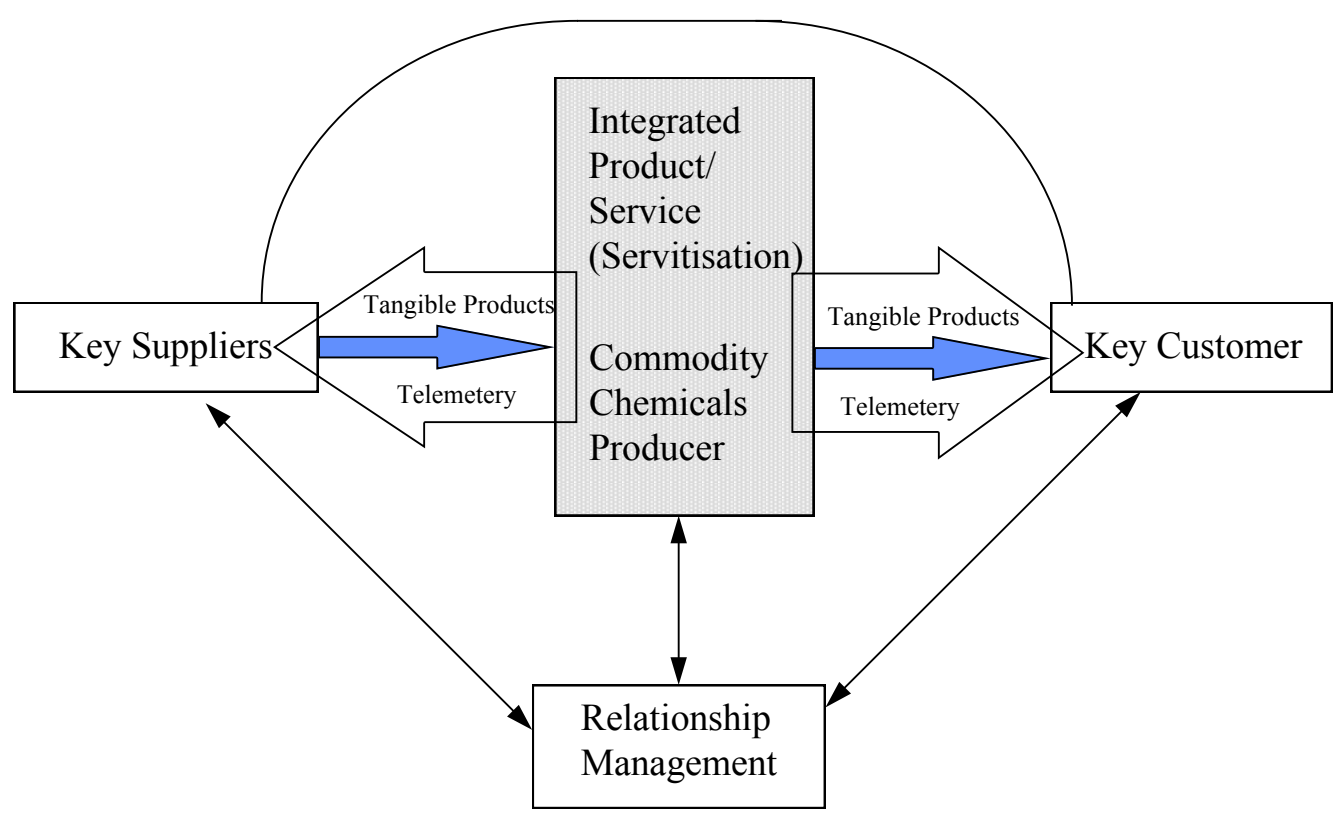

Commodity chemical firms have responded to the concept of servitisation in a variety of ways. Most notably through relationship building and reducing distance between the parties. This distance has both attitudinal and a physical dimensions. For example, one of the firms studied has linked its own production process with that of its customer by the use of continuous flow pipelines to the extent that both parties were effectively physically inseparable. Another firm studied used remote telemetry to monitor storage tank volumes at their customer's premises 
and adjusted flows into the plant accordingly. Another firm operated very short lead times on a JIT and EDI based logistical relationship in order to guarantee delivery patterns. All of this suggests that one of the key tenets of services marketing - the inseparability of production and consumption is equally valid at the commodity end of the continuum. However, such telemetry relationships have been found only with "key" customers rather than being the norm for all customers as might be the case in a "true" service company.

Does the present state of theory explain what is happening in the commodity sector? The authors would argue that services marketing theory is too pre-occupied with sectors where product and service differentiation are easily achieved. The challenge is to develop insights into non-differentiated markets where the service marketing issues for the producer are greatest. Future work should concentrate, initially on, the replication of this work in other industrial sectors characterised by commodity products and secondly to extend the use of the service marketing theory to industrial products.

\section{REFERENCES}

A. T. Kearney Chemical Industry Practice, 1996, Industry at a Crossroad: A Perspective. $\mathrm{h} t t p: / / w w w . a t k e a r n e y . c o m$.

A. T. Kearney Chemical Industry Practice, 1997, Challenging Chemical Companies to Change for Success. Http://www.atkearney.com.

Ahmed, P. K., 1991, Strategy, Structure and Performance in the UK Textiles and Engineering Industries. M. Phil Thesis, University of Huddersfield.

Alpha, 1996, Interview with the Sales Manager and the Planning and Business Development Manager at Alpha, 8th March.

Berry, L. L., 1980, Services Marketing is Different, Business, May-June, pp. 24-29

Beta, 1997, Special Report in European Chemical News.

Black, S., 1994, The Sulphur, Phosphorous, Nitrogen and Chlo-alkali Industries in The Chemical Industry edited by Heaton, A. Blackie Academic \& Professional, London.

Boneau, C., 1960, The Effects of Violations of Assumption Underlying the $t$ Test. Psychological Bulletin, Vol. 57, pp. 49-64.

Bryman, A. and D. Cramer, 1994, Quantitative Data Analysis for Social Scientists. Routledge.

Campbell, D. T. and D.W. Fiske, 1959, Convergent and Discriminate Validation of the Multitrait-multimethod Matrix. Psychological Bulletin, Vol. 56 No. 2, pp. 81-105.

Cespedes, F. V., 1994, Industrial Marketing: Managing New Requirements, Sloan Management Review, Spring, pp. 45-60. 
Clarke-Hill, C. M., T. M. Robinson and R. M. Clarkson, 1999, Service Strategy in Commodity Chemicals - Markets to Hierarchies: Escaping the Commodity Trap, International Journal of Customer Relationship Management, Vol. 2, no. 3, pp. 243-257.

Dess, G. G. and P.S. Davis, 1982, An Empirical Examinations of Porter's Generic Strategy. National Academy of Management Proceedings, August, pp. 7-11.

Dess, G. G. and P.S.Davis, 1984, Porter's (1980) Generic Strategies as Determinates of Strategic Group Membership and Organisational Performance. Academy of Management Journal, Vol. 27, pp. 467-488.

Dess, D. D. and A. Miller, 1993, Assessing Porter's (1980) Model in Terms of it's Generalizability, Accuracy and Simplicity, Journal of Management Studies, Vol. 30 No.4 pp. 553.

Easterby-Smith, M., R. Thorpe and A. Lowe, A., 1991, Management Research: An Introduction. Sage, London.

Emerson, W. S., 1983, Guide to the Chemical Industry. John Wiley, New York.

Games, P. and P. Lucas, 1966, Power of the Analysis of Variance of Independent Groups on Non-normally and Normally Transformed Data. Educational and Psychological Measurement, Vol. 26, pp.311-27.

Gamma, 1996, Strategy Document.

Ghemewhat, P. (1991) To Find Commitment: The Dynamics of Strategy. The Free Press, New York.

Hambrick, D.C., 1983, Some Tests of the Effectiveness and Functional Attributes of Miles and Snow's Strategic Types. Academy of Management Journal, Vol. 26, pp. 5-26.

Jick, T.D., 1979, Mixing Qualitative and Quantitative Methods: Triangulation in Action, Administrative Science Quarterly, Vol. 24, Dec, pp. 602-611.

Levitt, T., 1969, The Marketing Mode, McGraw-Hill, New York.

Levitt, T., 1972, Production Line Approach to Service, Harvard Business Review, September-October, pp. 41-42.

Lord, F.M., 1953, On the Statistical Treatment of Football Numbers. American Psychologist, Vol. 8, pp. 750-1.

Mitsch, R.A., 1996, The Emerging Customer-supplier Continuum. Chemistry \& Industry, December $2^{\text {nd }}$.

Morris, H. and L. F. Pitt, 1993, Do Strategy Frameworks Apply in the United States and Abroad? Industrial Marketing Management, Vol. 22, pp. 215-221. 
Popper, E. T. and B. D.Buskirk, 1992, Technology Life Cycles in Industrial Markets; Industrial Marketing Management, Vol. 21, pp. 23-31.

Porter, M. E., 1985, Competitive Advantage, The Free Press, New York.

Quinn, J. D., T. L. Doorley, and P. C. Paquette, 1990, Beyond Products: Service Based Strategy, Harvard Business Review, March/April, pp. 58-68.

Quintella, R. H., 1993, The Strategic Management of Technology: In the Chemicals and Petrochemicals industries. Pinter, London.

Rangan, V. K. and G. T. Bowman, 1992, Beating the Commodity Magnet. Industrial Marketing Management, Vol. 21 pp. 215-225.

Reichheld, F. F, 1996, The Quest for Loyalty. Chemtech, Vol. 26. No. 12 pp.14-18. This article was adapted from the introduction to The Quest for Loyalty: Creating Value Through Partnership, edited by Reicheld and published by Harvard Business School Press: Cambridge, MA 1996.

Robinson, T. M., C. M. Clarke-Hill and Richard Clarkson, Relationship Marketing and Business Strategy: A Case Study in the Commodity Chemicals Sector, International Journal of Customer Relationship Management, Spring 1999, Vol. 1, no. 3, pp 235-248

Shostack, G. L., 1977, Breaking Free from Product Marketing, Journal of Marketing, Vol.41, no.2, pp. 73-80.

Sinclair, S. A. and K. E. Seward, 1988, Effectiveness of Branding a Commodity Product. Industrial Marketing Management, Vol. 17 pp. 23-33.

Speed, R. J., 1989, Oh Mr Porter ! An Re-Appraisal of Competitive Strategy. Marketing, Intelligence and Planning, Vol. 7, No. 5/6 pp. 8-11.

Stobaugh, R., 1988, Innovation and Competition: The Global Management of Petrochemical Products. Harvard Business School Press, Boston.

Taylor, S., 1995, Statistical Analysis of Research Data. School of Human and Health Sciences, University of Huddersfield.

Unger, L., 1983, Strategic Planning for Commodities and Specialities, Long Range Planning, Vol. 16, No. 4, pp. 12-20.

Van Looy, B., R. Van Dierdonck, and P. Gemmel, 1998, Services Management: An Integrated Approach, Financial Times Pitman, London.

Vandermerwe, S. and J. Rada, 1988, Servitisation of Businesses: Adding Value by Adding Service, European Management Journal, Vol. 6, no. 4, pp. 314-324.

Webb, E. J., D. T. Cambell, R.D. Schwartz, and L. Sechrest, 1966, Unobtrusive Measures Nonreactive Research in the Social Sciences, and McNally and Company, Chicago 
Wei, J., T. W. F. Russell and M. W. Swartzlander, 1979, The Structure of the Chemical Processing Industries. McGraw-Hill, New York.

Yin, R. K., 1994, Case Study Research: Design and Methods, Sage, London, 2nd Edition.

Note: Full citations for Alpha, Beta and Gamma have been restricted to preserve confidentiality agreements. 
